\title{
Histologic evaluation of the effect of mineral trioxide aggregate-Fillapex as a root canal sealer in rat teeth submitted to late replantation
}

\author{
Manuel Marques Ferreira ${ }^{1}$, Maria Filomena Botelho ${ }^{1}$, Margarida Abrantes ${ }^{1}$, \\ Lina Carvalho ${ }^{1}$, Eunice Carrilho ${ }^{1}$
}

Correspondence: Dr. Manuel Marques Ferreira

Email:m.mferreira@netcabo.pt
'Department of Dentistry, Faculty of Medicine, University of Coimbra, Coimbra, Portugal

\section{ABSTRACT}

Objective: This study aims to analyze the effect of new root canal based silicate cement, in rat teeth after late replantation, comparing with calcium hydroxide $(\mathrm{CH})$ in preventing tooth root resorption. Materials and Methods: The study group included 16 Wistar rats in which the upper right central incisors were extracted and were left on a worktable for 60 min, simulating a case of tooth avulsion, after had been anesthetized. One group, (Group I), the canals were filled with $\mathrm{CH}$ past, before replantation. The second groups of teeth, (Group II), the canals were filled with mineral trioxide aggregate-Fillapex (MTAF). After removal, the blood clot of the socket, with saline solution irrigation, the teeth were replanted into their original socket, and splinted with silk 3/0. The rats were sacrificed 8 weeks after replantation and the specimens were prepared for histologic and histomorphometric analyses. The areas of inflammatory and replacement resorptions were selected and quantified. These data for each group of teeth were evaluated and analyzed using the Mann-Whitney test $(P=0.05)$. Result and Conclusion: All the replanted teeth in both groups survived. Although root canal filled with MTAF provide better results than with $\mathrm{CH}$ past concerning inflammatory and replacement resorption, there was no statistical difference $(P=0.527)$.

Key words: Avulsion, dental trauma, replantation, root canal filling, root surface treatment, survival rate

\section{INTRODUCTION}

Traumatic dental injuries due to vehicle accidents, sports, and accidental falls are very frequent. The most severe of the traumatic dental injuries is avulsion, which is known as a complete displacement of the tooth from the socket. The maxillary central teeth are the most often affected, mainly in children who have lip incompetence and protrusion of incisors with increased overjet. The incidence of tooth avulsion ranges from $0.5 \%$ to $3 \%$ of all traumatic injuries to permanent dentition. ${ }^{[1]}$

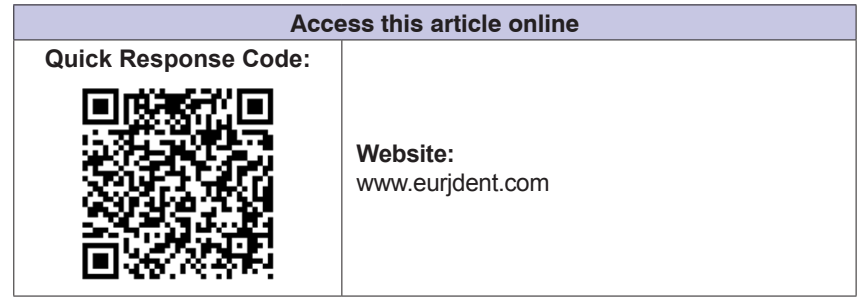

Although ideal treatment in cases of avulsion is the immediate replantation, when delayed replantation occurs, there is dehydration and necrosis of the periodontal ligament (PDL) cells, which can complicate the prognosis. ${ }^{[2]}$

According to the International Association of Dental Traumatology and traumatology guidelines, in case of delayed replantation, a variety of adjunctive

This is an open access article distributed under the terms of the Creative Commons Attribution-NonCommercial-ShareAlike 3.0 License, which allows others to remix, tweak, and build upon the work non-commercially, as long as the author is credited and the new creations are licensed under the identical terms.

For reprints contact: reprints@medknow.com

How to cite this article: Ferreira MM, Botelho MF, Abrantes M Carvalho L, Carrilho E. Histologic evaluation of the effect of mineral trioxide aggregate-Fillapex as a root canal sealer in rat teeth submitted to late replantation. Eur J Dent 2017;11:89-93.

DOI: 10.4103/ejd.ejd_106_16 
treatments have been proposed to prevent and delay root resorption, increasing the survival of replanted teeth.

Immersion the teeth into $2 \%$ acidulated phosphate sodium fluoride for $5 \mathrm{~min}$, is considered a good solution to prevent the inflammatory root resorption and ankylosis of replanted teeth. ${ }^{[3]}$

After late replantation, it is recommended to remove the pulp tissue and fill the root canal with calcium hydroxide $(\mathrm{CH})$ dressing for a long period, to prevent the inflammatory and replacement root resorption.

$\mathrm{CH}$ is recommended as a root canal dressing, due to its alkaline $\mathrm{pH}$ and bactericidal effect that make changes of the environment, which may slow or avoid inflammatory root resorption and promote hard tissue formation. ${ }^{[4]}$

However, the changing of the $\mathrm{CH}$ should be kept to a reduced time, because it may induce degeneration of collagen fibers in root dentine that may lead to ankyloses. On the other hand, successive changes of $\mathrm{CH}$ weak the teeth, which increases fracture susceptibility and loss of the teeth. ${ }^{[5,6]}$

Although, the worth of control the contamination of the pulp and dentine using $\mathrm{CH}$ as a canal dressing, another option is the immediate obturation of the root canal with a sealer and gutta-percha (GP). ${ }^{[7]}$

Thus, the search for new substances that may inhibit or delay the effects of root resorption is demanding.

Mineral trioxide aggregate (MTA) cement has been widely used in procedures such as pulp capping, pulpotomy, apexification, root perforation repair, as an alternative to $\mathrm{CH}$.

Positive findings have been reported that MTA as to its biocompatibility, antimicrobial activity, and inductive potential for mineralized bone formation has the similar clinical response of tooth tissues as $\mathrm{CH}$, involving the release of calcium and hydroxyl ions. ${ }^{[8-11]}$

An endodontic sealer based on MTA cement (MTA-Fillapex - Angelus Industria de Produtos Odontlogicos Ltda., Londrina, Brazil) claims to take advantage of the biological and physical properties as the MTA. ${ }^{[12]}$

MTAF, apart from containing MTA compounds, this sealer contain resins, radiopaque bismuth, silica, and pigments and is showed suitable physical properties to be used as an endodontic sealer to be recommended for root canal filling.

Although some authors describe a similar tissue response when compared with the original MTA formulations, the biological responses to MTAF in replanted teeth have not yet been explored..$^{[13,14]}$

The aim of this study was to analyze the effect of MTAF as a root canal sealer in avulsed replanted teeth, compared with $\mathrm{CH}$.

\section{MATERIALS AND METHODS}

Sixteen Wistar rats weighing about 250-300 g were used in this study. The study was approved by the Institutional Board on Animal Experimentation (Of. Ref 24-CE-2011). The animals were acquired from Institute for Biomedical Imaging and Life Sciences (IBILI)-FMUC-PT and experimental procedures were performed in IBILI-FMUC PT, in accordance with the International Guiding Principles for Animal Research.

All the experimental procedures were performed by the same operator, with the animals under general anesthesia.

For surgical interventions, the animals were anesthetized by intramuscular injection of a mixture of Ketamine (Imalgene ${ }^{\circledR} 1000$, Merial) $80-100 \mathrm{mg} / \mathrm{kg}$ and Xilazine (Rompum ${ }^{\circledR} 2 \%$, Bayer), $5-10 \mathrm{mg} / \mathrm{kg}$ and all efforts were made to minimize the animals' suffering. After anesthesia, antisepsis of the anterior portion of the maxilla was achieved by the use of Clorhexidine 0.2\% (Laboratoires Pierre Fabre Médicament 45, Abel-Gance, 92100 Boulogne-France).

After cutting the PDL fibers and luxation, the maxillary right central incisors were extracted and were the left on a worktable for $60 \mathrm{~min}$, simulating a case of tooth avulsion. Afterwards, the dental papillae of the teeth were sectioned with a blade no. 15 and the pulp tissue was extirpated through a retrograde through with a K file \#20 (Dentsply Maillefer, Ballaigues, Switzerland). Root canals were prepared and were irrigated with $1 \%$ sodium hypochlorite using a syringe and a needle. After mechanical removal of the PDL with gauze embedded in 1\% hypochlorite solution (Dentaflux, El Nogal 28110-Algete-Madrid, Spain), the teeth was washed with sterile saline solution and then immersed in $20 \mathrm{ml}$ of $2,72 \%$ acidulate 
phosphate sodium fluoride ( $\mathrm{pH}$ 5.5), (Dentaflux, El Nogal 28110-Algete-Madrid, Spain) for $10 \mathrm{~min}$. The root canals were dried with sterilized paper points and filled according the groups: Group I, the canals were filled with $\mathrm{CH}$ past (Cuxhaven, Germany) using a Luer lock syringe and a $25 \mathrm{G}$ gauge needle and Group II, the canals were filled with MTAF sealer (Angelus Industria de Produtos Odontlogicos Ltda, Londrina, Brazil). After removal the blood clot of the socket, with saline solution irrigation, the teeth were replanted into their original socket, and splinted with silk $3 / 0$. The rats were sacrificed 8 weeks after replantation, the jaws with experimental teeth were harvested, fixed in 10\% formalin solution for $24 \mathrm{~h}$ and decalcified. After decalcification with 17\% ethylenediaminetetraacetic acid solution at $\mathrm{pH} 7.0$, the specimens were processed and embedded in paraffin. Transversal sections with 6 - $\mu$ m-thick were obtained and only those from the middle-third were considered and stained with hematoxylin and eosin for histologic and histomorphometric analyses.

\section{Histological analysis}

The images of the root sections were analyzed by light microscopy (Nikon Eclipse 80i) with respect to the characteristics of the PDL, cementum and dentin of each experimental group. The chosen sections were acquired using a digital device camera Nikon DXm1200C, with fixed magnification $\times 40$ and saved for analysis. The areas of inflammatory and replacement resorptions were chosen, quantified with Image J (National Institutes of Health, United States) and data were saved in Excel 1.4 software (Microsoft Corporation, Redmond, WA, USA) for statistical analysis. Root perimeter measurements allowed for quantification of the areas of ankylosis. The total root surface perimeter and the perimeter of the areas of ankylosis were measured. Mann-Whitney test were used for statistical analysis to compare the reduced rank regression analysis between the groups.

\section{RESULTS}

All the Wistar rats tolerated the operative procedures well, and their behavior did not change. No teeth were lost and the number of replanted teeth was 16 .

Histologic images showed only one tooth in the $\mathrm{CH}$ group with inflammatory response in the tissue surrounding the replanted tooth.

In the teeth filled with MTAF, no inflammatory response was seen.
Areas of fibrous connective tissue were observed in both groups and their irregular organization around the tooth indicates the formation of healing repair tends toward the development of ankyloses. In all the groups, it was evident the replacement root resorption in witch were repaired with alveolar bone tissue.

In one specimen of $\mathrm{CH}$ group, collagen disorganized fibers are displayed to the root surface [Figure 1].

In two specimens of MTAF group, areas of dense connective tissue were found. A very small amount of MTAF material were found in the adjacent tissue of the roots of two specimens, phagocyted by macrophages, but without inflammatory root resorption and inflammatory infiltrate [Figure 2].

\section{Statistical analysis}

After quantification, the obtained values were subjected to statistical analysis with $\mathrm{IBM}^{\circledR} \mathrm{SPSS}^{\circledR} \mathrm{V} .20$ software (Statistical Package for the Social Sciences, IBM, Chicago IL) $(\alpha=0.05)$.

The results show that there was no statistically significant difference between the groups regarding the occurrence of replacement root resorption $(U=26.00$; $Z=-0.632 ; P=0.527$ ) [Figure 3].

Group MTAF was less affected by inflammatory resorption and it presented less areas of replacement root resorption (40.29\%), than did CH Group (50.06\%).

\section{DISCUSSION}

This experimental model has been performed in rats, according several studies related to tooth replantation.

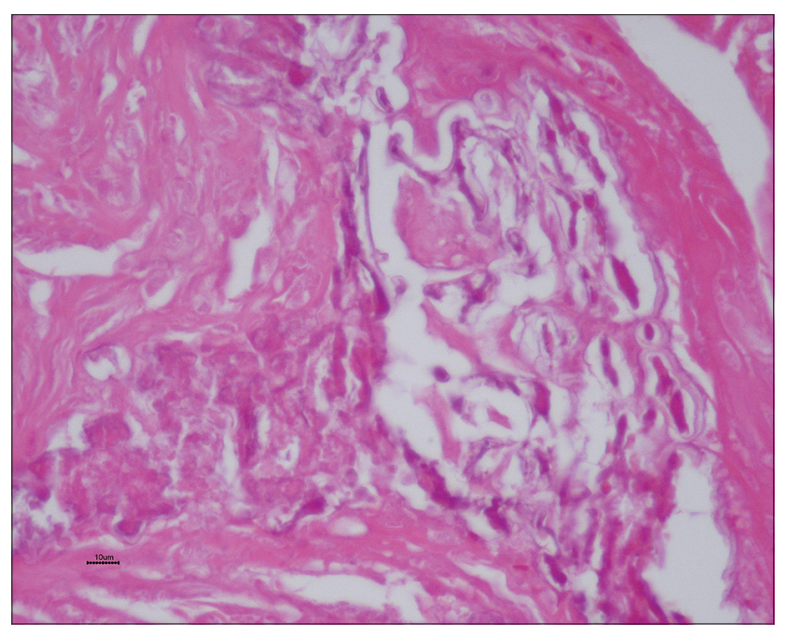

Figure 1: Response in the tissue surrounding the replanted tooth with inflammatory response in the calcium hydroxide Group ( $\mathrm{H}$ and $\mathrm{E}, \times 400)$ 


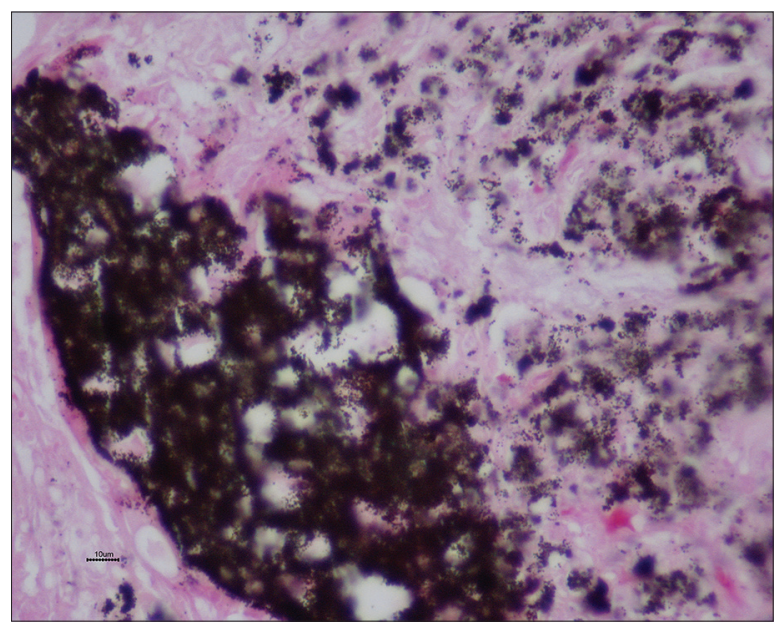

Figure 2: Response in the tissue surrounding the replanted tooth without inflammatory response in the mineral trioxide aggregate Fillapex Group (H and E, ×400)

As rat incisor is a continuously eruption root growth, we removed the dental papilla to stop the eruption and the teeth were left dry for $60 \mathrm{~min}$ to simulate the condition of delayed tooth replantation in human teeth.

After long period of extra-oral time the presence of necrotic PDL remnants could contribute to the inflammatory process by the release of several enzymes and inflammation mediators along the course of the healing process. To prevent the effect of the necrotic PDL cells, the removal of PDL remnants of the root surface has been recommended. ${ }^{[15]}$

For this purpose, was used $1 \% \mathrm{NaOCl}$ to remove the remnants of necrotic PDL cells.

Studies showed that Zoledronic acid applied in the root surface of late replanted teeth, was able of limiting the occurrence of root resorption and preserving cementum resorption. Recently studies revealed, the use of enamel matrix derivatives (Emdogain), on periodontal regeneration by cementum in periodontal wound healing. ${ }^{[16]}$ Emdogain contains an enamel matrix protein extracted from developing porcine embryonic enamel in a sterilized aqueous solution of propylene glycol alginate.

Immersion of the teeth during $5 \mathrm{~min}$ in Fluoride $2 \%$, was recommended due to its osteoclast-inhibiting and their enzymatic activity, replacing the hydroxyapatite layer for a fluorapatite layer expecting to make the root more resistant to resorption. ${ }^{[17]}$

In this study, areas of fibrous connective tissue were observed and their irregular organization around the tooth indicates the formation of healing repair

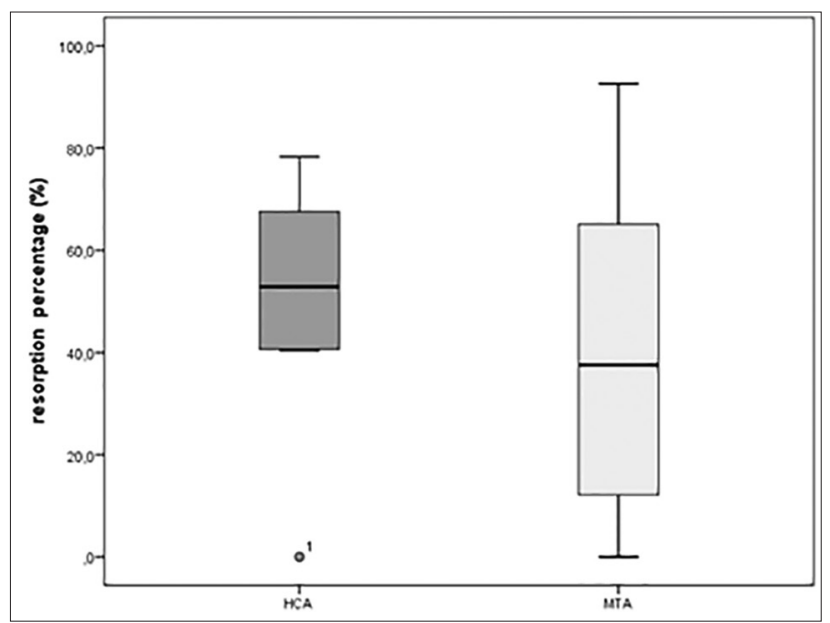

Figure 3: The percentages of replacement root resorption in the groups. HCA: Calcium hydroxide; MTAF: Mineral trioxide aggregate Fillapex

tends toward the development of ankylosis, which is probably due to the absence of living cells in the PDL. ${ }^{[18]}$

Although $\mathrm{CH}$ is considered the intra canal dressing of choice in the prevention of inflammatory root resorption, has the disadvantage of a detrimental effect on the fracture resistance of dentin, when used for long-term, leads to weakness. ${ }^{[19,20]}$

Based on in vitro studies, some authors postulated that the exposure of dentin to $\mathrm{CH}$, contributed to the degradation of Type I collagen, due to the reduction of the metalloproteinase inhibitor, tissue inhibitor of metalloproteinase-2 (TIMP-2). This effect increase when $\mathrm{CH}$ dressing is refreshed, increasing the available of $\mathrm{CH}$ and the weakening effect on fracture resistance. ${ }^{[21-24]}$

MTA has been developed and is demonstrated that the antibacterial properties, biocompatibility and mechanism of action has some similarities of $\mathrm{CH}$. However, the use of MTA, for final filling of the root canal is difficult and still remains uncertainty. $\mathrm{CH}$ is one of the major active ingredients of MTA and has been shown that MTA induce a protective effect on TIMP-2. ${ }^{[25]}$

Given the good properties of calcium silicate MTA cements, MTA-based endodontic sealers for root canal obturation have been developed recently as MTAF.

Since MTAF cement have been introduced as a contemporary sealer a limited studies have been dedicated to its properties as a root canal filling material in late replanted teeth. The possibility to replace the extended use of $\mathrm{CH}$ dressing, by the immediate and 
definitive obturation sealer, comparing its action and behavior in late replanted teeth it is appealing.

In this experimental study, was used MTAF paste-to-paste, which when in contact promotes chemical reactions that are responsible to set the material. We filled the root canal with $\mathrm{CH}$ or MTAF, without GP cones, based in a microscopic study, that evaluate the tissue response in delayed rat tooth replantation after root canal filled with $\mathrm{CH}$ past or Sealapex and Endofil, without GP cones. ${ }^{[6]}$

The biocompatibility of MTAF, was demonstrated in the present study, when this material is in contact with periapical tissues, without the development of inflammatory infiltrate.

Although MTAF provides better results than with $\mathrm{CH}$ past, concerning inflammatory and replacement resorption, there was no statistical difference.

Due the properties of MTAF and the fact that set hard inside the root canal, it could be used in the management of avulsed teeth rather than $\mathrm{CH}$ past, to prevent crown fracture.

\section{CONCLUSION}

Under the conditions of this study, there appears insufficient evidence to support that MTAF decrease the root resorption in late replanted teeth after avulsion.

The MTAF, a sealer with the same properties as $\mathrm{CH}$, have the advantage that it is not necessary to refresh the inter appointment dressing regularly, preventing root canal reinfection and fracture of the teeth.

\section{Financial support and sponsorship}

Nil.

\section{Conflicts of interest}

There are no conflicts of interest.

\section{REFERENCES}

1. Andersson L, Andreasen JO, Day P, Heithersay G, Trope M, Diangelis AJ, et al. International Association of Dental Traumatology guidelines for the management of traumatic dental injuries: 2 . Avulsion of permanent teeth. Dent Traumatol 2012;28:88-96.

2. Flores MT, Andersson L, Andreasen JO, Bakland LK, Malmgren B, Barnett F, et al. Guidelines for the management of traumatic dental injuries. II. Avulsion of permanent teeth. Dent Traumatol 2007;23:130-6.

3. Bjorvatn K, Selvig KA, Klinge B. Effect of tetracycline and SnF2 on root resorption in replanted incisors in dogs. Scand J Dent Res 1989;97:477-82.
4. Sjögren U, Figdor D, Spångberg L, Sundqvist G. The antimicrobial effect of calcium hydroxide as a short-term intracanal dressing. Int Endod J 1991;24:119-25.

5. Trope M, Moshonov J, Nissan R, Buxt P, Yesilsoy C. Short vs. long-term calcium hydroxide treatment of established inflammatory root resorption in replanted dog teeth. Endod Dent Traumatol 1995;11:124-8.

6. Trope M, Yesilsoy C, Koren L, Moshonov J, Friedman S. Effect of different endodontic treatment protocols on periodontal repair and root resorption of replanted dog teeth. J Endod 1992;18:492-6.

7. Lengheden A, Blomlöf L, Lindskog S. Effect of immediate calcium hydroxide treatment and permanent root-filling on periodontal healing in contaminated replanted teeth. Scand J Dent Res 1991;99:139-46

8. Tronstad L, Andreasen JO, Hasselgren G, Kristerson L, Riis I. $\mathrm{pH}$ changes in dental tissues after root canal filling with calcium hydroxide. J Endod 1981;7:17-21.

9. Holland R, de Souza V, Nery MJ, Bernabé oF, Filho JA, Junior ED, et al. Calcium salts deposition in rat connective tissue after the implantation of calcium hydroxide-containing sealers. J Endod 2002;28:173-6.

10. Marão HF, Panzarini SR, Aranega AM, Sonoda CK, Poi WR, Esteves JC, et al. Periapical tissue reactions to calcium hydroxide and MTA after external root resorption as a sequela of delayed tooth replantation. Dent Traumatol 2012;28:306-13.

11. Parirokh M, Torabinejad M. Mineral trioxide aggregate: A comprehensive literature review - Part III: Clinical applications, drawbacks, and mechanism of action. J Endod 2010;36:400-13.

12. Vitti RP, Prati C, Silva EJ, Sinhoreti MA, Zanchi CH, de Souza eSilva MG, et al. Physical properties of MTA Fillapex sealer. J Endod 2013;39:915-8.

13. Kim M, Yang $\mathrm{W}$, Kim $\mathrm{H}, \mathrm{Ko} \mathrm{H}$. Comparison of the biological properties of ProRoot MTA, OrthoMTA, and Endocem MTA cements. J Endod 2014;40:1649-53.

14. Silva EJ, Rosa TP, Herrera DR, Jacinto RC, Gomes BP, Zaia AA Evaluation of cytotoxicity and physicochemical properties of calcium silicate-based endodontic sealer MTA Fillapex. J Endod 2013;39:274-7.

15. Sottovia AD, Sonoda CK, Poi WR, Panzarini SR, Lauris JR. Delayed tooth replantation after root surface treatment with sodium hypochlorite and sodium fluoride: Histomorphometric analysis in rats. J Appl Oral Sci 2006;14:93-9.

16. Ferreira MM, Filomena BM, Lina C, Barbara O, Palmeirao CE. The effect of emdogain gel on periodontal regeneration in autogenous transplanted dog's teeth. Indian J Dent Res 2014;25:589-93.

17. Flores MT, Andreasen JO, Bakland LK, Feiglin B, Gutmann JL, Oikarinen K, et al. Guidelines for the evaluation and management of traumatic dental injuries. Dent Traumatol 2001;17:193-8.

18. Andreasen JO, Farik B, Munksgaard EC. Long-term calcium hydroxide as a root canal dressing may increase risk of root fracture. Dent Traumatol 2002;18:134-7.

19. Valera MC, Albuquerque MT, Yamasaki MC, Vassallo FN, da Silva DA, Nagata JY. Fracture resistance of weakened bovine teeth after long-term use of calcium hydroxide. Dent Traumatol 2015;31:385-9.

20. Batur YB, Erdemir U, Sancakli HS. The long-term effect of calcium hydroxide application on dentin fracture strength of endodontically treated teeth. Dent Traumatol 2013;29:461-4.

21. Ferreira M, Simões R, Carrilho E. Removal of calcium hydroxide of the root canal: convencional irrigation vs sonic. Rev Port Estomatol Med Dent Cir Maxilofac 2014:55:97-101.

22. Böttcher DE, Hirai VH, Da Silva Neto UX, Grecca FS. Effect of calcium hydroxide dressing on the long-term sealing ability of two different endodontic sealers: An in vitro study. Oral Surg Oral Med Oral Pathol Oral Radiol Endod 2010;110:386-9.

23. Calt S, Serper A. Dentinal tubule penetration of root canal sealers after root canal dressing with calcium hydroxide. J Endod 1999;25:431-3.

24. Kim SK, Kim YO. Influence of calcium hydroxide intracanal medication on apical seal. Int Endod J 2002;35:623-8.

25. Hatibovic-Kofman S, Raimundo L, Zheng L, Chong L, Friedman M, Andreasen JO. Fracture resistance and histological findings of immature teeth treated with mineral trioxide aggregate. Dent Traumatol 2008;24:272-6.

26. Negri MR, Panzarini SR, Poi WR, Sonoda CK, Gulinelli JL, Saito CT. Analysis of the healing process in delayed tooth replantation after root canal filling with calcium hydroxide, Sealapex and Endofill: A microscopic study in rats. Dent Traumatol 2008;24:645-50. 